\title{
Streptanthus purpureus spec. nova (Cruciferae), an endemic nickel hyperaccumulator from Sierra Nevada (California, USA)
}

\author{
Daniel Sánchez-Mata (*), Vicenta de la Fuente (**), Lourdes Rufo (**), \\ Nuria Rodríguez (***) \& Ricardo Amils (****)
}

\begin{abstract}
Sánchez-Mata, D., de la Fuente, V., Rufo, L., Rodríguez, N. \& Amils, R. Streptanthus purpureus spec.nova (Cruciferae), an endemic nickel hyperaccumulator from Sierra Nevada (California, USA). Lazaroa 34: 275-283 (2013).

The genus Streptanthus Nutt. (Cruciferae) is one of the most important indicators of ultramafic floras in Western North America. This genus contains taxa that are endemic or tolerant of ultramafic soils. One of these taxa, Streptanthus polygaloides sensu lato (s.1.) are annual nickel hyperaccumulators strictly confined to ultramafic soils throughout the Californian Sierra Nevada foothills. Some clarifications are discussed regarding the taxonomy and ecology of this complex, leading to the recognition of a new taxon: Streptanthus purpureus sp. nova.
\end{abstract}

Keywords: Streptanthus polygaloides, Streptanthus purpureus, SEM.

Resumen: Sánchez-Mata, D., de la Fuente, V., Rufo, L., Rodríguez, N. \& Amils, R. Streptanthus purpureus spec. nova (Cruciferae), un hiperacumulador de níquel endémico de la Sierra Nevada californiana (California, USA). Lazaroa 34: 275-283 (2013).

El género Streptanthus Nutt. (Cruciferae) es uno de los principales bioindicadores de sustratos ultramáficos en el oeste de Norteamérica. Este género incluye táxones endémicos o tolerantes de este tipo de hábitats extremos. Uno de ellos, Streptanthus polygaloides sensu lato (s. 1.), es un terófito hiperacumulador de níquel endémico exclusivo de los sustratos ultramáficos distribuidos por Sierra Nevada (California). En esta contribución se aportan datos acerca del hábitat y la ecología de este complejo reconociéndose y justificándose un nuevo taxon que se propone al nivel específico: Streptanthus purpureus sp. nova.

Palabras clave: Streptanthus polygaloides, Streptanthus purpureus, MEB.

\section{INTRODUCTION}

Streptanthus polygaloides s.l. is a complex group found only on ultramafic soils in the westfacing foothills of the Sierra Nevada (KRUCKEBERG, 1984). This is a large mountain range, 80 $\mathrm{km}$ wide and $400 \mathrm{~km}$ long, in a generally northsouth direction, and reaching elevations of 4,400 $\mathrm{m}$. The main rock types in the great Sierra Nevada batholit are granitic rocks (granodiorite, quartz monzonite, tonalite, etc.), which are capped by volcanics and flanked on the western side by older ultramafic rocks (HILL, 2006).

The complex distribution is limited to the ultramafic Californian Sierra Nevada landscapes, and is a strictly serpentine endemic (SAFFORD \& al., 2005). The general coverage of Streptanthus polygaloides s.l. ranges from the foothills (mesomedi-

* Departamento de Biología Vegetal II. Facultad de Farmacia. Universidad Complutense. E-28040 Madrid, Spain. E-mail: dsmata@farm.ucm.es

** Departamento de Biología. Facultad de Ciencias. Universidad Autónoma de Madrid. Cantoblanco, E-28049 Madrid, Spain. E-mail: vicenta.fuente@uam.es, lourdes.rufo@uam.es

*** Centro de Astrobiología (INTA-CSIC). Torrejón de Ardoz, E-28850 Madrid, Spain. E-mail: nrodriguez@cbm.uam.es

**** Centro de Biología Molecular (UAM-CSIC). UniversidadAutónoma de Madrid. Cantoblanco, E-28049 Madrid, Spain. E-Mail: ramils@cbm.uam.es 
terranean thermotype) to mountain and high-mountain areas (supra-oromediterranean thermotype). In its biogeographical range, $S$. polygaloides s. 1. characterizes annual plant communities in the phytosociological alliance Streptanthion polygaloidis Rodríguez-Rojo, Sánchez-Mata, Rivas-Martínez \& Barbour 2001 (RoDRíGUEZ-RoJo \& al., 2001b; SÁNCHEZ-MATA, 2007). These communities cover a broad altitudinal range, usually between $350-1200$ $\mathrm{m}$, throughout ultramafic areas in the foothills of the Sierra Nevada. The populations exhibit two morphotypes: flowers with yellow sepals at lower elevations and with purple sepals at higher elevations.

Moreover, Streptanthus polygaloides s.l. is a well-known nickel hyperaccumulator (REEVES \& al., 1981; REEVES, 1992; KRUCKEBERG \& al., 1995; BROOKS, 1998; NiCKS \& CHAMBERs, 1998; SÁNCHEZ-MATA \& al., 2004; BOYD \& al., 2009).

\section{MATERIALS AND METHODS}

\section{PlANT MATERIAL}

All plant samples studied are from our own collection or from herbarium specimens. All the detailed data from the studied material are summarized in the Appendix 1.

\section{SAmple Preparation for Scanning Electron MICROSCOPY}

Pollen grains and seeds were observed by SEM. For seeds, dry samples were fixed in situ with formyl acetic alcohol (FAA). After washing with a $0.1 \mathrm{M}$ phosphate buffer ( $\mathrm{pH} 7.4)$, they were dehydrated through a graded ethanol series. Dry samples were mounted flat on the surfaces of conductive graphite stubs and sputtered and goldcoated in a Bio-Rad SC 502 apparatus for electrical conductivity and to prevent charging under the electron beam. Samples were examined with a Hitachi S-3000N (Japan) SEM using an acceleration voltage of $20 \mathrm{kV}$ and a working distance of $15 \mathrm{~mm}$. The temperature of the sample stage during analysis was room temperature.

\section{MORPHOLOGICAL DATA}

The width of the sepals (upper, lower and the pair of laterals), the length of petals, and the length and width of seeds and pollen grains from the specimens collected and also from herbarium material (see Appendix 1) were measured. A total of 24 populations and 50 individuals were analyzed.

\section{STATISTICAL ANALYSIS}

Statistical analyses were carried out on plant data using Statistica release 6.0 (Statsoft Inc., Tulsa, USA). Means, medians, standard deviations and standard errors were calculated. Data were log-transformed after being tested for normality with the Shapiro-Wilk test $(p>0.05)$ and for homogeneity of variance with the Levene test $(p>0.05)$. In order to test possible differences between two groups we used the Student's t-test. Means of three or more groups were compared by one-way analysis of variance. Bonferroni corrections between means were calculated only if an $\mathrm{F}$ test was significant at the 0.05 level of probability.

\section{RESULTS AND DISCUSSION}

Streptanthus polygaloides s.l. is an ephemeral therophyte from the Cruciferae family. The vegetative structures are glabrous-glaucescent showing basal leaves rosulate, early-deciduous; the blades of rosette leaves $(2-20 \mathrm{~cm})$ are wavy-dentate or 1-2 pinnately lobed with broadly linear to filiform lobes; caulinar leaves $(1-10 \mathrm{~cm})$ sessile, linear, entire and base auriculate-lobed (AL-SHEHBAZ, 2010, 2012). The most peculiar characters of this taxon are located in the flowers, which are strongly zygomorphic with an urceolate and markedly bilateral calyx; sepals are light yellow (lower altitude populations) or purple (higher altitude populations); there are existing populations that show yellow-purplish sepals as an intermediate character; the adaxial sepals are larger than the abaxial; the abaxial are suborbicular to broadly ovate-cordate, forming a distinctive banner- 
like hood, keeled, 4-6 x 6-8 mm; petals are subincluded or barely exserted, purplish or brownish, especially on the veins. The fruit is a straight and reflexed siliqua.

Streptanthus polygaloides was first described and proposed as a new species by Asa GRAY (1865) based on the study of specimens collected by Professor William H. Brewer, a botanist of the State Geological Survey of California, in an ultramafic territory: 'On very dry hillsides in serpentine soil, along the Tuolumne River'. Gray's protologue description includes some comments about the peculiarity of the dissimilarity of the light-yellow petaloid sepals, indicating that this species may deserve to be framed in a special section of the genus Streptanthus Nutt.

GREENE (1889) wrote some specific comments about the peculiarity of the floral morphology of Streptanthus polygaloides. In his Flora Franciscana (GREENE, 1891) he placed this unique species in a special group of the genus Streptanthus characterized by "Calyx very irregular, the uppermost sepal greatly enlarged, in aestivation conduplicate over the others". Finally, this author (GREENE, 1904) proposed the new monotypic genus Microsemia to place Gray's Streptanthus, based on its peculiar flower development and morphology: Microsemia polygaloides (Gray) Greene. Despite its treatment as a unique taxon within the Streptanthus genus in the recently edited Jepson Manual (AL-SHEHBAZ, 2012) we agree with the opinion of this author published in Flora of North America (AL-SHEHBAZ, 2010) on the variability of this taxon and the need for an integrated study.

We know that the specimens from Brewer's collections from the Californian Sierra Nevada ultramafic (serpentine) territories are preserved, at least, in the Harvard University Herbaria [Gray Herbarium (GH00019713)] and in the Herbarium of the Royal Botanic Gardens, Kew (K000653792). In both cases the specimens were collected by W.H. Brewer in 1863 and show the same collection number: \# 1615. Moreover, the labeled localities are different: the Harvard specimens are labeled from the locus classicus and the Kew specimens are labeled from "Sierra Nevada". All the specimens considered as type specimens (even the Harvard specimen properly labeled as "type spe- cimen" by D.W. Taylor in 1994 and also studied by Al-Shehbaz from the protologue locality) show purple sepals in contrast with the description published by Asa Gray in the protologue: “...light-yellow...sepals...". Possibly the original collection was mixed when it was distributed or mounted on herbarium sheets combining specimens and labels: the populations from the Tuolumne River must show light-yellow sepals as described in Gray's protologue, while specimens with purple sepals were collected in higher elevations throughout territories in the Sierra $\mathrm{Ne}$ vada broad territory (Tuolumne River Basin).

We paid several visits to the type locality of Streptanthus polygaloides Gray in the ultramafic areas of the Sierra Nevada foothills (Tuolumne River, Tuolumne County) and surrounding ultramafic territories. We consistently found that all the populations growing in these territories show light-yellow sepals as published by Asa Gray in the protologue. The area clearly shows a mesomediterranean thermotype $(<500 \mathrm{~m}$ asl altitude) with serpentine shrub communities as natural vegetation (Medeiros, 1984; Evens \& al., 2004; ALEXANDER \& al., 2007).

At higher elevations throughout utramafic areas in the Sierra Nevada (usually $>900 \mathrm{~m}$ ), purple sepals populations are found separately and we have not observed individuals with intermediate characters coexisting with them. We agree with PoPE \& al. (2013) that these populations with intermediate characters (Y/P sepals) are morphotypes with a extremely limited geographic distribution and should be considered as hybrids. The chromosome number given by RoLLins (1993) is 2n:28, as has been found in other Streptanthus species.

The Streptanthus polygaloides s.l. populations over $900 \mathrm{~m}$ asl altitude show a group of important morphological characteristics that are maintained among these populations as flowers with large deep purple sepals, subincluded petals, and big seeds with a prominent wing in the distal tip, which are considered essential to recognize them as a rank of species. Therefore we propose a new taxon for these populations growing in supra-oromediterranean territories exclusively on ultramafic outcrops throughout the Sierra Nevada landscapes: 


\section{Streptanthus purpureus spec. nova}

Habito similar Streptanthus polygaloides Gray. Hoc novum species differt quod habet purpureos et magnos sepalos [superior (8.5)-8.8-10.2-(10.3) mm lati; inferior (4.5)-4.7-6.1-(6.2) mm lati et laterales 2-3.1-(3.2) mm lati], subaequales longitudine petaliis, petalos (5.5)-6.0-6.5-(7.0) mm long $i$ et semina elliptico-ovata, $1.53-2.15 \mathrm{~mm}$ longa et 0.89-1.11 mm lata, reticulata-foveata, apice distalia alata. Habitat in locis serpentinis aridis montium de Sierra Nevada, Californiae, altitudine superiori quam Streptanthus polygaloides Gray.

Annual, with simple stems or branched distally; leaves basal, rosetted and early-deciduous, mid-cauline sessile, base auriculated, and distal reduced; inflorescence open, bilateral; flowers with calyx urn-shaped; sepals deep purple, upper (8.5)-8.8-10.2-(10.3) mm wide, broadly ovatecordate forming a banner-like hood; lower sepal
(4.5)-4.7-6.1-(6.2) mm wide, broadly ovate, keeled; lateral pair of sepals 2-3.1-(3.2) mm wide lance-ovate; petals (5.5)-6.0-6.5-(7.0) $\mathrm{mm}$ long not clearly exerted; pollen reticulate $20-27 \mu \mathrm{m}$ long, $12-15 \mu \mathrm{m}$ wide; siliqua pendent, straight, valves glabrous; pedicels strongly recurved; seeds elliptico-ovate, $1.53-2.15 \mathrm{~mm}$ long and 0.89-1.11 $\mathrm{mm}$ wide, reticulate-foveate, with a prominent wing at the distal apex.

The new proposed taxon differs from Streptanthus polygaloides Gray for its bigger and purple sepals almost of the same length as petals; petals 5.5-7.0 mm long and seeds ellliptico-ovate, reticulate-foveate and with a remarkable wing at the distal tip (apex) -almost circumtexte wing (woven all round) in Streptanthus polygaloides Gray-.

Chromosome number account of $2 \mathrm{n}=28$ (RoLLINS, 1993) was included by Al-Shehbaz in its recent monograph of the California Streptanthus taxa (Al-Shehbaz 2012). We do not know the precise location of the studied populations.
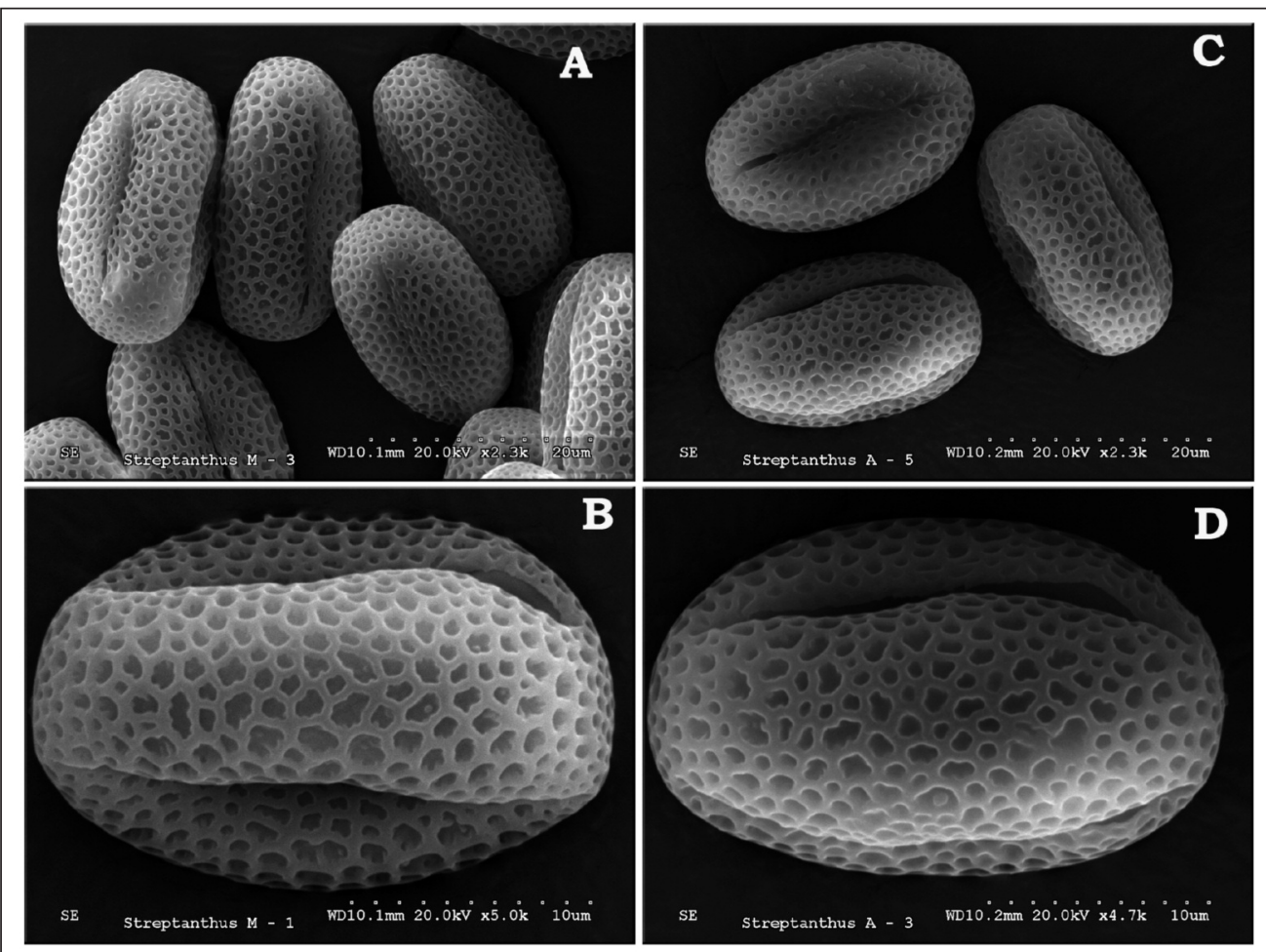

Figure 1. - Representative SEM micrographs of pollen grains of Streptanthus purpureus (A, B) and Streptanthus polygaloides (C,D) samples. A and C. Several pollen grains; B and D. Detail of reticulate ornamentation of pollen grains in equatorial view. 
Pollen grains of selected populations of Streptanthus polygaloides (23-26 $\mu \mathrm{m}$ long, 13-16 $\mu \mathrm{m}$ wide) and Streptanthus purpureus (20-27 $\mu \mathrm{m}$ long, 12-15 $\mu \mathrm{m}$ wide) had the same size ( $p>$ 0.05 ) and a similar reticulated ornamentation (Figure 1). Figure 2 shows the seeds: from Streptanthus purpureus specimens were elliptico-ovate, $1.53-2.15 \mathrm{~mm}$ long and $0.89-1.11 \mathrm{~mm}$ wide, reticulate-foveate, with a prominent wing at the distal apex; the seeds from Streptanthus polygaloides specimens were elliptico-ovate, (1.11)-1.23-1.83 (1.85) $\mathrm{mm}$ long and $0.74-0.98 \mathrm{~mm}$ wide, reticulate-foveate, with a almost circumtexte wing.

It grows in ultramafic (serpentine) mountain and high mountain areas of Sierra Nevada (California) at higher altitudes that the typical subspecies $(>900 \mathrm{~m})$.

Type specimens: California, Placer County. Forest Hill, Sugar Pine Road to Sugar Pine Reservoir. Open annual grasslands developed on ul-
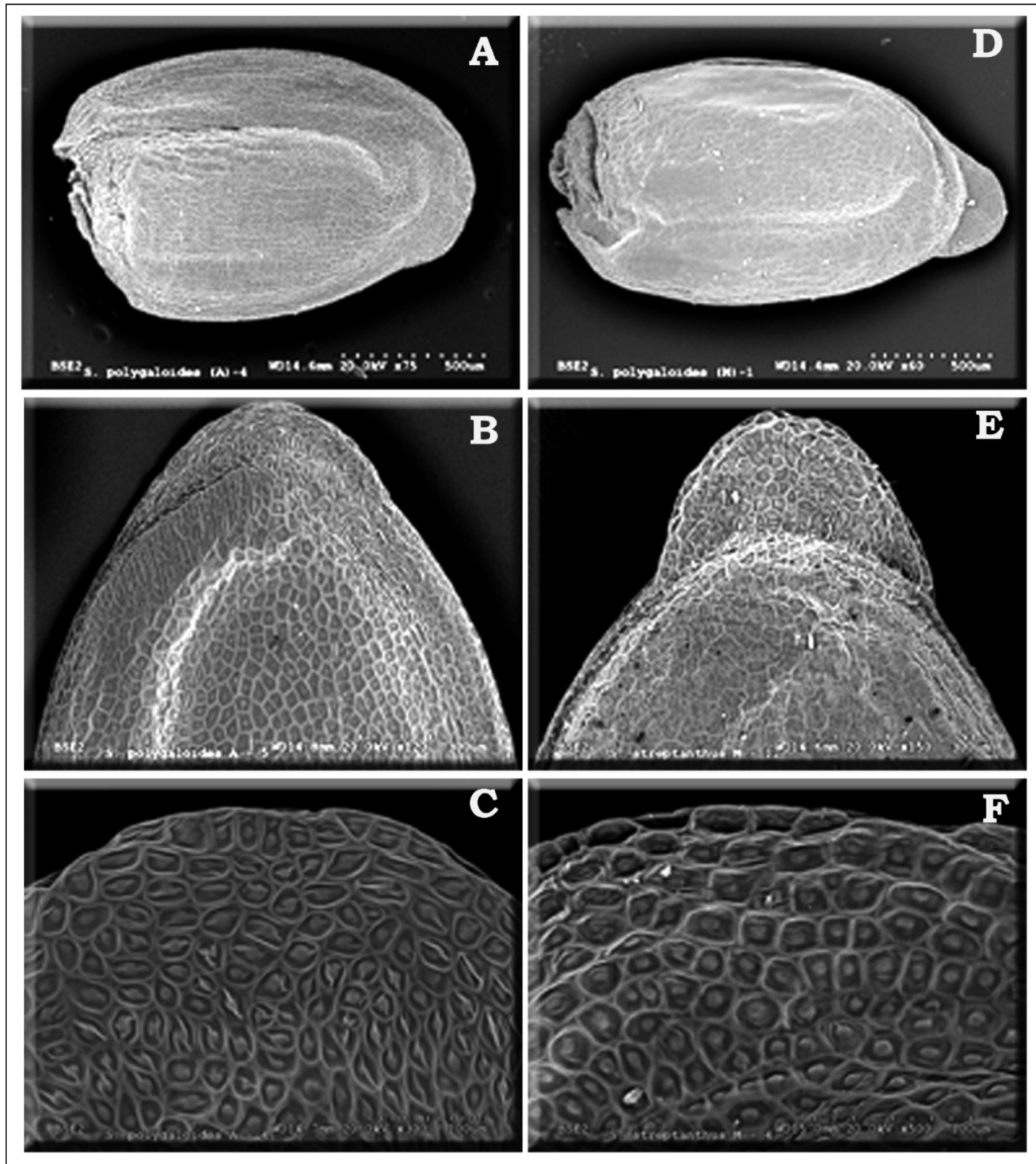

Figure 2. - Representative SEM micrographs of seeds of Streptanthus polygaloides (A, B, C) and Streptantus purpureus (D, E, F) samples. A and D. Micrographs of the complete seeds; B and E. Detail of the extension and morphology of the wings in the distal tip of the seed; C and F. Detail of the reticulate-foveate ornamentation. 
tramafic (serpentine) fine debris (Streptanthion polygaloidis Rodríguez-Rojo \& al. 2001), 1150 $\mathrm{m}, 120^{\circ} 45^{\prime} \mathrm{W}, 39^{\circ} 07^{\prime} \mathrm{N}$, in Pacific ponderosa pine open forest environments (Pinus ponderosa subsp. pacifica). 23.VI.2004. Leg. D. SánchezMata (Holotypus, MAF 171942; isotypus, MAF 171941. Isotype material will be deposited in the following institutional herbaria: DAV, JEPS, WTU, K, P, G, M, MA).

The new proposed species is a very frequent taxon throughout the serpentine areas of the Sierra Nevada highlands, structuring ephemeral annual grasslands with very low coverage and developed on serpentine debris or talus.

Streptanthus polygaloides characterizes the annual and ephemeral grasslands developed on ultramafic (serpentine) soils throughout the territories in the Sierra Nevada: the Streptanthion polygaloidis phytosociological alliance (RoDRíGUEZ-RoJo \& al., 2001b) framed in the classis Vulpio microstachyos-Hesperolinetea micranthi Rodríguez-Rojo \& al. 2001 (RoDRíGUEZ-RoJo \& al., 2001b). Within this specific alliance we recognize two community groups: 1 . Lowland grasslands: Streptanthetum polygaloidis Rodríguez-Rojo \& Sánchez-Mata 2001 (RodRíGUEz-RoJo \& al., 2001a) described in El Dorado County, California
(Placerville-Georgetown, $620 \mathrm{~m}$ asl altitude) as the type of the alliance; and 2. Mountain-area communities, from $900 \mathrm{~m}$ asl altitude, structured by the new taxon proposed here, showing deep purple sepals (Streptanthus purpureus). These orophyte communities deserve further phytosociological studies.

\section{ACKNOWLEDGEMENTS}

This study was supported by grant CGL2009-11059 y CGL2008-901 from the Ministry of Education and Science (Spanish Government), and other institutional grants such as that of the Centro de Biología Molecular Severo Ochoa (CBMSO), and the Centro de Astrobiología. Moreover, the "Del Amo" program of the Complutense University in Madrid (UCM) supported the yearly research program of one of the authors (DSM) at the University of California (UC) where Prof. Michael G. Barbour (Plant Sciences) and Ellen Dean (UC Davis Center for Plant Diversity) helped in different ways. REMEDINAL2 program from the Autonomous Government of Madrid (S2009/AMB-1783) also financed part of this research. We would also like to thank Dr. $\mathrm{M}^{\mathrm{a}}$ Felisa del Barrio Vega, a classical Latin Professor at the Complutense University, for her expert translation of the new taxon diagnosis, Pru Brooke-Turner helped with the English version of the original manuscript, and Dr. Enrique Rodríguez Cañas from the SEM Unit of the Interdepartmental Investigation Service (SIDI) of Autonomous University (Madrid), for his help in the microscopical analysis.

\section{REFERENCES}

Al-Shehbaz, I.A. - 2010 - Streptanthus - In: Flora of North America Editorial Committee (Eds.) 1993+. Flora of North America North of Mexico, vol. 7. Pp. 700-723. Oxford Univ. New York.

Al-Shehbaz, I.A. - 2012 - Streptanthus - In: Baldwin, B.G, Goldman, D.H., Keil, D.J., Patterson, R. \& Rostti,T.J. (Eds.). The Jepson Manual. Vascular Plants of California. Pp. 566-573. University of California Press. Berkeley.

Alexander, E.B., Coleman, R.G., Keeler-Wolf, T. \& Harrison, S.P. -2007- Serpentine Geoecology of Western North America. Geology, Soils, and Vegetation. Oxford University Press. New York.

Boyd, R.S., Wall, M.A., Santos, S.R. \& Davis, M.A. - 2009Variation of morphology and elemental concentrations in the Californian nickel hyperaccumulator Streptanthus polygaloides (Brassicaceae). Northeast. Nat. 16 (5): 21-38.

Brooks, R.R. - 1998 - Plants that hyperaccumulate heavy metals: their role in phytoremediation, microbiology, archaelogy, mineral exploration and phytomining. $\mathrm{CAB}$ International. Wallingford-Oxon.
Evens, J.M., San, S . \& Taylor, J. - 2004 - Vegetation classification and mapping of Peoria Wildlife Area, South of New Melones Lake, Tuolumne County, CA - California Native Plant Society. Sacramento.

Gray, A. - 1865- Characters of some New Plants of California and Nevada, chiefly from the Collections of Professor William H. Brewer, Botanist of the State geological Survey of California, and of Dr. Charles L. Anderson, with revisions of certain Genera or Groups - Proc. Am. Acad. Arts Sci. 6: 519-556.

Greene, E.L. - 1889- Analogies and affinities, II - Pittonia 2: 40-50.

Greene, E.L. - 1891 - Flora Franciscana. An attempt to classify and describe the vascular plantas of Middle California - San Francisco.

Greene, E.L. - 1904- Certain West American Brassicaceae - Leaf. Bot. Observ. Crit. 1: 81-91.

Hill, M. -2006- Geology of the Sierra Nevada - In: Faber, P.M. \& Pavlik, B.M. (Eds.). Rev. ed. California Natural History Guide Series No. 80. Univ. California Press, Berkeley. 
Kruckeberg, A. - 1984- California serpentines: flora, vegetation, geology, soils, and management problems University of California Press. Berkeley.

Kruckeberg, A.R. \& Reeves, R.D. - 1995- Nickel accumulation by serpentine species of Streptanthus (Brassicaceae): Field and greenhouse studies - Madroño 42(4): 458-469.

Medeiros, J. - 1984- Serpentine flora: notes on prominent sites in California, the Red Hills - Fremontia 11(5): 2829.

Nicks, L.J. \& Chambers, M.F. - 1998 - A pioneering study of the potential of phytomining for nickel - In: Brooks, R.R. (Ed.). Plants that hyperaccumulate heavy metals: their role in phytoremediation, microbiology, archaelogy, mineral exploration and phytomining. Pp. 313-325. CAB International, Wallingford-Oxon.

O’Geen, A.T., Dahlgren, R. A. \& Sánchez-Mata, D. 2007- Ultramafic Vegetation - In: Barbour, M.G., Keeler-Wolf, T., Schoenherr, A.A. (Eds.). Terrestrial Vegetation of California (3rd edition). Chapter 3, California Soils and Examples of Ultramafic Vegetation. Pp. (71)93-106. Univ. California Press, Berkeley.

Pope, N., Fong, M., Boyd R.S. \& Rajakaruna, N. -2013The role of elevation and soil chemistry in the distribution and ion accumulation of floral morphs of Streptanthus polygaloides Gray (Brassicaceae), a Californian nickel hyperaccumulator - Plant. Ecol. Div. DOI: 10.1080/ 17550874.2013.783141.

Reeves, R.D. - 1992 - The hyperaccumulation of nickel by serpentine plants - In: Baker, A.J.M., Proctor, J. \&
Boyd, R.S. (Eds.). The vegetation of ultramafic (serpentine) soils. Pp. 253-277. Intercept Limited, Andover.

Reeves, R.D., Brooks, R.R., Macfarlane, R.M. -1981Nickel uptake by Californian Streptanthus and Caulanthus with particular reference to the hyperaccumulator S. polygaloides Gray (Brassicaceae) - Am. J. Bot. 68(5): 708-712.

Rodríguez-Rojo, Ma .P., Sánchez-Mata, D., Gavilán García, R.G., Rivas-Martínez, S., Barbour, M.G. -2001aTypology and ecology of the Californian serpentine annual grasslands - J. Veg. Sci. 12(5): 687-698.

Rodríguez-Rojo, Mª.P., Sánchez-Mata, D., Rivas-Martínez, S., Barbour, M.G. - 2001b - Syntaxonomical approach for classification of the Californian serpentine annual grasslands - Lazaroa 22:83-94.

Rollins, R.C. - 1993 - The Cruciferae of Continental North America. Systematics of the Mustard Family from Artic to Panama - Stanford University Press, Stanford.

Safford, H.D., Viers, J.H., Harrison, S. -2005- Serpentine endemism in the California flora: a database of serpentine affinity - Madroño 52: 222-257.

Sánchez-Mata, D., Rodríguez González, N., Rodríguez-

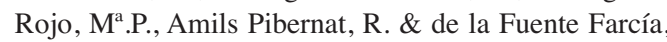
V. -2004- Studies on California's ultramafic flora: a selected microanalytical screening - In: Boyd, R.S., Baker, A.J.M. \& Proctor, J. \& col. (Eds.). Ultramafic Rocks: their Soils, Vegetation and Fauna. Pp 259-261. Science Reviews, St. Albans. 


\section{APPENDIX 1}

Selected abbreviated references taken from the data provided by the participants of the Consortium of California Herbarium (ucjeps.berkeley.edu/consortium/; October, 2013) listed by California counties and data; other data from the Herbarium of the Faculty of Pharmacy at the Complutense University of Madrid (MAF):

\section{Streptanthus polygaloides Gray}

Butte: CAS301797, DS333339, JEPS25036, SBBG29856, UC659997: Magalia, South Branch of Feather River, 487 m, Lincoln Constance 2826, 28.05.1941; CAS775507, CHSC40446: West of Lunt Road, north of Yankee Hill, 550 m, L. Ahart 4975, 15.05.1985; CAS849292, CHSC44382: Poe Power House Road, southeast of Jarbo Gap, 365 m, Lowell Ahart 6034, 30.05.1988; CAS886271, CHSC39956: Northeast of Concow Reservoir, 550 m, L. Ahart \& P. Ahart 4178, 30.06.1983; CAS899638, CHSC62721: South of Serpentine Point above Hwy 70, 518 m, L.P.Janeway 4334, 02.05.1993; CDA13890, CHSC75483: North of Magalia, above Little Butte Creek, east of Holmwood Drive, 740 m, G.F. Hrusa \& T.D. Wilfred 13747, 08.05.1997; -CHSC78133, JEPS98473: Kunkle Creek-Lake Oroville, east of the Kunkle Power House, southeast of Paradise, 335 m, Lowell Ahart 8419, 31.05.2000; CHSC93454, HSC96717, JEPS108792: Bardees Bar Road, southwest of Pulga, 354 m, Lowell Ahart 12612, 10.05.2006; CHSC93944: Concow Road, northeast of Concow Reservoir, 860 m, L.P. Janeway 8639, 28.05.2006; CHSC95039, HSC96689: West side of Coutelenc Road, north of Skyway at "Magalia Serpentine", 713 m, L.P. Janeway 8693, 25.06.2006; CHSC95054: Northwest side of Rim Road at southern end of Rocky Ridge, 847 m, L.P. Janeway 8647, 28.05.2006; CHSC95057, HSC96718: Westside of Lunt Road, southwest of Hwy 70, 495 m, L.P. Janeway 8648, 28.05.2006; CHSC97726: Lake Oroville, east of Power House below Kunckle Reservoir, north of the Lime Saddle Campground, $271 \mathrm{~m}$, Lowell Ahart 14552, 11.03.2007.

El Dorado: CHSC98907: Traverse Creek Special Interest Area, 692 m, L.P. Janeway 9098, 08.07.2007; MAF155429: Placerville-Georgetown, Bear Creek Road-Meadow Brook Road, 640 m, 10SFN8905, D. Sánchez-Mata, 09.08.1997; MAF158431: Green Valley Road, westside of Placerville, 300 m, 10SFN8187, MªP. Rodríguez-Rojo, 0608-1997; UCD70585, DAV139886: northeast of Placerville, along Bear Creek Road, near Traverse Creek, Ellen Dean $\&$ al. 369, 17.05.1997.

Fresno: CAS1119845, JEPS118805: Dry Creek Basin, Red Mountain, 725 m, Dana York 902, 16.06.1996; DS343842, GH422248, POM275196, UC709348: Below Trimmer, near Kings Rivers, 198 m, Ella Carter 58, 02.06.1943.

Mariposa: CAS408398: Bagby-Coulterville, Peter H. Raven \& Harlan Lewis 9393, 10.06.1956; DS42807, DS95570, GH422259, POM143220: Bagby, on the Merced River, 275 m, H.M. Hall 8841, 20.05.1911; RSA239052: north of Mariposa, S. Carlquist 4364, 24.05.1973; UC956590: Road to Coulterville north of Bagby, Freed W. Hoffman 2392, 04.10.1948.

Nevada: CAS143525, DS158072, GH422247, POM118178, UC18971: Over Bear River, near Gautier Bridge, 450 m, H.M. Hall \& F.M. Esig 10161, 07.06.1916.

Placer: MAF172397: Between Nevada City and Grass Valley, 760 m, D. Sánchez-Mata \& T. Santamaría, 20.06.2006; MAF172398: Forest Hill, Forest Hill Road to Moshiron Road, 600 m, D. Sánchez-Mata, 20.05.2004.

Tuolumne: CAS 1106664: Red Hills BLM Area of Critical Environmental Concern, 335m, R.C. Wenk 1068, 09.05.2009; CHSC106276: Red Hills, 380 m, L.P. Janeway \& B. Castro 10035, 27.06.2010; JEPS104817, RSA695884: Hwy 49, north of Coulterville, 518 m, D.W. Taylor 15096B, 23.06.1995.

\section{Streptanthus purpureus}

Nevada: CAS572692, CAS883805: Washington Road, 1280 m, G.H. True \& J.T. Howell 2225, 14.07.1965; CAS572694, CAS883802, RSA584259, UCR77868: Washington Road, north of Washington Junction, 1341 m, G.H. True \& T. Howell 6100, 17.07.1970; CAS572837: Relief Hill Road, west of Poorman Creek, 853 m, Gordon H. True 2888, 25.05.1966; CAS572838: Washington, Washington Hidrolic Mine, 1219 m, Wayne Roderick s.n., 08.07.1967; CAS572839: Washington Road, north of Washington, 1341 m, Gordon H. True 1601, 22.0.1964; CAS572840: Newton Road, Newton-Indian Flat, 716 m, Gordon H. True 6671, 08.06.1971; CAS886269: South Yuba River, below Washington, 792 m, Lillian Mott 48LM74, 06.06.1974; CAS886270: South side of South Yuba River, below Washington, 792 m Gordon H. True \& Hohn Thomas Howell 7686, 23.05.1974; MAF158432, MAF158433, MAF158434: Tahoe National Forest, 1200 m, 10FP8956, MP. Rodríguez-Rojo \& D. Sánchez-Mata 31.07.1997; MAF158432, MAF158433, MAF158434, UCD69207, DAV138581: Tahoe National Forest, Washington Ridge, 1200 m, P. Rodríguez-Rojo \& D. Sánchez-Mata, 31.07.1997; MAF172394: Between Nevada City and Newton, Newton Road, 730, D. Sánchez-Mata 
\& T. Santamaría, 20.06.2006; MAF172395: Between Nevada City and Newton, Newton Road, 730, D. Sánchez-Mata, 05.06.2004; RSA167177, SFV1524, UCD116108, DAV33332: On Road to Washington, L.K. Mann s.n. 14.07.1963; UCD116107, DAV 184671: Washington Road, R.O. Hanes 268, 14.07.1995; UCD116113, DAV62998: West of Poorman's Creek, 823-853 m, Grady L. Webster 7516, 24.06.1967; UCD127657, DAV199420: Washingon Road, 1371 m, A.M. Shapiro s.n., 03.10.2010.

Placer: MAF 171941, MAF 171942 : Forest Hill, Sugar Pine Road to Sugar Pine Reservoir, 1150 m, $120^{\circ} 45^{\prime}$ W, 3907’ N, D. Sánchez-Mata, 23.06.2004; MAF171337 : Forest Hill, Iowa Hills Road to Sugar Pine Reservoir, 1100 m, $39^{\circ} 07^{\prime}$ N, $120^{\circ} 46^{\prime}$ W, D. Sánchez-Mata \& T. Santamaría, 28.07.2008; MAF172393: Forest Hill, Mosquito Ridge Road, 850 m, D. Sánchez-Mata, 23-06.2004; MAF172396: Dutch Flat, Drum Power House Road, 1070 m, D. Sánchez-Mata, 12.06.2004.

Sierra: CAS572843, DS572842: West of Downievillw, 807 m, R.C. Barneby \& John Thomas Howell 11477 , 12.05.1954; CAS572844, DS445216, GH42225, UC1199883: North Fork of the Yuba River, opposite Goodyears Bar, 853 m, Herbert L. Mason 14899, 24.05.1959; CAS797532: South of Alleghany, 1300 m, Lowell Ahart s.n., 04 .06.1978; CDA25180, CHSC94121, HSC96843, JEPS108764, RSA718447, SBBG119805: West side of the Foote Road, southwest of Alleghany, 1093 m, L. Ahart 12807. 21.06.2006; CHSC32062, UCD116041, DAV118546: East of the Foote Road, southwest of Alleghany, 914 m, L. Ahart 236-237, 25.05.1973; CHSC43432: Near the Foote Road, south of Alleghany, 1219 m, L. Ahart 1768, 04.06.1978; CHSC67648: North of Fournier Ranch, on the south slope Above Ladies Creek, 1341 m, James D. Jokerst 2152, 23.07.1984; CHSC78239. JEPS98601, JEPS98720: At the intersection of Mountain House Road and Henness Pass Road, 1462 m, Lowell Ahart 8474, 15.06.2000; GH422252, UC614608: West of Downieville, above north fork of Yuba River, 853 m, L. Constance 2293, 0806.1938; HSC96850, JEPS108763: West of Forest, 1398 m, L. Ahart 12830, 21.06.2000; JEPS26982: Downieville, Mrs. Adeline Frederick, 06.1925; RSA509431, UCR54443: Above Ramshorn Campground, west of Downieville, 823 m, B. Pitzer \& al. 868, 27.05.1988; SJSU4976: Between Foote's Crossing and Alleghany, N.A. Hopkins 273, 30.06.1969; SJSU8321: Goodyears Bar, west of Downieville, 833 m, C.L. Kline 104, 29.06.1965; SJSU8351: North of Goodyears Bar at junction with State Hwy 49, 833 m, W. Savage 441, 29.07.1965; UCD116106, DAV36284: West of Downieville, 833 m, Gerald Dickinson 18, 21.06.1963; UCD116111, DAV40336: GoodyearsBar turnoff, 833 m, P.B. Schultz 23, 30.06.1967. 